\title{
Properties of Bio-Fermented Milk as Influenced with the Addition of Chicory (Cichorium intybus L) Roots Powder
}

Abd El-sattar T. G. ${ }^{1}$; M. M. Abo-Srea ${ }^{2}$; and T. H. EL-Sawah ${ }^{3}$

${ }^{1}$ Departement of dairy research Food Technology Research Institute, Agric. Research Center, Giza, Egypt

${ }^{2}$ Dairy Department, Faculty of Agriculture, Mansoura University., El Mansoura, Egypt

${ }^{3}$ Dairy Tech. Research, Department. Animal Production Research Institute, Agriculture Research Center, Dokky, Giza, Egypt

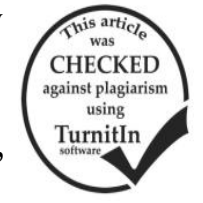

\begin{abstract}
In an attempt to improve the properties of free-fat yogurt, 3, 6\% of Chicory (Cichorium intybus L) root base powder (CRP) or their extracted inulin (3 and 6\%) were added to defatted milk. A combined culture of Streptococcus thermophilus-St-36, Lactobacillus delbrueckii subsp. bulgaricus- Lb-12and Bifidobacterium bifidum(Bb-11) was used in the fermentation process. The obtained results revealed that protein, total solids and ash significantly increased; also the $\mathrm{pH}$ and acidity were affected by the addition of CRP and inulin powder during the storage. CRP and inulin treatments resulted in the highest levels of acetaldehyde and total volatile essential fatty acid (TVFA) which increased by prolonging the storage period. Addition of CRP and inulin to fermented milk significantly increased the survival of Lb. delbruekii spp. bulgricus and B. bifidum bacteria. The numbers of Lb. delbruekii spp. bulgricus showed a clear fall which was statistically significantly different $(\mathrm{p}<0$. 05$)$ from the initial counts after 8 days. Nevertheless the addition of inulin ( 3 and $6 \%$ ) to milk was of compared milk more effective than the addition of CRP ( 3 and 6\%) during the storage period. Addition of CRP increased curd tension and lowered the synersis of biofermented milk. Regarding organoleptic properties, insignificant similarities were found among the $3 \%$ fat control and $6 \%$ of CRP or inulin treatments.
\end{abstract}

Keywords:- bio-fermented milk, Cichorium intybus, Roots powder, inulin, free-fat yoghurt.

\section{INTRODUCTION}

One of the important kinds of functional food is reduced fat products, particularly, low fat dairy food in order to combat obesity, cardiovascular disease and hypertension (NRC. 1989). Chicory (Cichorium intybus L) is an abundant source of inulin which represents 44 . $69 \%$ of its dry weight. Massoud et al., (2009). Inulin is a polymer of fructose with (2 -1) glycosidic linkage. Inulin act as a functional substance because it has many attributes such as its sugar and fat replacement, texturizing, and bulking agent. Also, it is used for its physical features of being solucionable dietary fiber and having prebiotic properties (Causey et al. 2000). On the other hand, inulin is a dietary fiber with limited calorie value, subsequently, suited to diabetics and is regarded as beneficial to health for its prebiotic properties. Inulin has been determined as an ingredient which it has been termed as prebiotic and plays a role in the elimination and inhibition of digestive tract and breast cancer (Taper et al., 1995 and1997). Furthermore to calorie and fat loss, it had a fiber effect, lipid modulation and bifibus stimulation. Intended for these reasons, chicory is widely used as a functional food throughout the world for their health promoting and technological properties.

Inulin has a pleasant taste and not has any abnormal colours, so, it has minimal effect on the sensory properties of a product. Moreover, the use of inulin giving a significantly improve of the taste properties because of its combining with high intensity sweeteners. Inulin strongly used for dairy products fortification over the other classical fiber due to its high solubility. This fortification can be take place in yoghurt, cheese, drinks and deserts, which have been normally quandary in it's fortify (Niness, 1999)

Plain unsweetened natural yoghurts containing inulin was preferred over samples without inulin in consumer tests. That yoghurt was determined to be creamier, having a less chalky and creamier texture, and have pleasant sour fermented pre and after taste (Spiegel, et al., 1994).

Yogurt considered as one of the dairy products, which should continue to increase in sales due to the creation on its types in the range of yoghurt-like products. Fermented foods consumed as probiotics when active live bacteria be add to it during its making. Many varieties of milk products can be contribute in this roll or as a functional foods such as soy milk yoghurt and yoghurt. Many beneficial promoting parameters expected to occur when fermented milk by common yoghurt starter or probiotic starter bacteria were consumed, one of these is the modification of the gut micro flora and the replacement of hazardous microbes by beneficial bacterias i. e. probiotics, which can be reflected in the health improvement which causes the prolong the age (Metchnikoff 1907, Yadav et al., 2015 and Dello Staffoloa, et al., 2004).

Therefore, this study aims to investigate the ability of producing free fat functional yoghurt by using Chicory (Cichorium intybus L) roots powder or extracted inulin as fat substitutes and study the chemical, Rheological, Microbiological and sensory properties of resultant bio- fermented milk.

\section{MATERIALS AND METHODS}

Fresh buffalo's milk was obtained from the herds of the Faculty of Agriculture, Kafr El-Sheikh University and defatted, Lyphilyzed cultures of yoghurt Streptococcus thermophilus-St-36 + Lactobacillus delbrueckii subsp. Bulgaricus - Lb-12) and B. bifidum (Bb-11) were obtained from Chr. Hansen'Lab. Copenhangen, Denmark. Chicory (Cichorium intybus) roots were collected from Sakha Agric. Res. Station. Pure Inulin was obtained from Sigma Chemical. Co.

Preparation of Chicory (Cichorium intybus L) roots powder (CRP): Raw Chicory roots were carefully washed with tap water, and were cut into small pieces, heated in water $85^{\circ} \mathrm{C}$ for $30 \mathrm{~min}$ and blended, then 
freeze dried. The recovered powder was kept in polyethylene bags, and stored at $7 \pm 2^{\circ} \mathrm{C}$ until use. The chicory roots were chemically analyzed. Inulin of chicory roots were extracted and determined according to the El-Farra (1989). Fresh chicory root contained, in dry weight, $67 \%$ inulin, $15 \%$ sucrose, $6.5 \%$ protein, $4.5 \%$ cellulose, $3.8 \%$ ash, and $3.2 \%$ other compounds. Dried chicory root extract contains, in weight, about $98 \%$ inulin and $2 \%$ other compounds.

Preparation of fermented milk : The fresh milk was defatted, heated at $95^{\circ} \mathrm{C} / 15 \mathrm{~min}$, cooled immediately to $40^{\circ} \mathrm{C}$, then inoculated with $3 \%(\mathrm{w} / \mathrm{v})$ of mixed bulk culture $(1: 1: 1)$, of Streptococcus thermophilus- St-36, Lactobacillus delbrueckii subsp. Bulgaricus - Lb-12 and B. bifidum (Bb-11).

The cultured defatted milk was divided into 5 portions. The first portion was taken as control (without inulin or chicory root), chicory root powder $3 \%$ and $6 \%$, inulin $3 \%$ and $6 \%$ individually were added to the other portions. A control with fat $3 \%$ and without additive was prepared. Every portion was inoculated with $3 \%$ w/v mixed culture (1:1:1) of Streptococcus thermophilus, St-36 and Lactobacillus delbrueckii Subsp. bulgaricus, Lb-12 and B. bifidum (Bb-11), and packaged in plastic cups (50 gm each), and incubated at $40 \pm 2^{\circ} \mathrm{C}$ until complete coagulation. The produced fat free Zabady-bifidum fermented milk was stored at $7 \pm 2^{\circ} \mathrm{C}$, and analyzed when fresh (after overnight cold storage) and after 4, 8 and 12 days of storage for chemical, microbiological, rheological properties and sensory evaluation.

Chemical analysis: Protein, total solids, titratable acidity, ash and $\mathrm{pH}$ value were determined according to Ling (1963). Total Volatile fatty acid (TVFA) was determined according to Kosikowski (1978), Acetaldehyde content was estimated according to the Conway micro diffusion semicarbazed method, as described by Lees and Jago(1969).

Rheological properties analysis: The curd tension (firmness) was determined as described by Chandrashekhara et al. (1957). Syneresis (whey separation) was determined as described by Hassan et al. (1999).

Enumeration of Lactic acid bacteria: $S$. thermophilus was enumerated on ST agar after incubating the plates aerobically at $37^{\circ} \mathrm{C}$ for $24 \mathrm{~h}$, using MRS agar at $\mathrm{pH} 5.2$, and incubation at $40^{\circ} \mathrm{C}$ for $72 \mathrm{~h}$ were carried out for the enumeration of $L$. delbrueckii ssp. bulgaricus. The viable numbers of bifidobacteria were enumerated according to the method of Tharmaraji, and Shah (2003) using MRS-L (lithium chloride and L-cystein chloride) agar. The inoculated plates were incubated anaerobically at $37^{\circ} \mathrm{C}$ for $72 \mathrm{~h}$. Plates containing 25 to 250 colonies were enumerated and recorded as colony forming units (CFU) per gram of sample.

Sensory evaluation: The sensory evaluation was assessed according to El-Shibiny et al. (1979) using the following points for different properties: Appearance (10 points), body \&texture (30 points), and flavor (60 points).

Statistical analyses:_Data analysis was carried out with SPSS Inc. software (version 10.0; SPSS Inc., Chicago,
IL), and statistically different groups were determined by the DUNCAN's Multiple Rage test (Steel \& Torrie, 1980). All data are presented as average \pm standard error.

\section{RESULTS AND DISCUSSION}

Chemical analysis: Total solid (\%), protein (\%) and ash $\%$ of fresh bio-fermented milk samples were shown in Table 1. High Significant differences were recorded in total solids and protein content of CRP (6\%) and inulin (6\%). Protein content ranged between 3.19-4.14\%. In addition, CRP $6 \%$ and $3 \%$ gained the highest protein and Ash contents $(0.8$ and 0.88$)$. Data of the total solids illustrated in the same Table reveal that there isn't significant difference between CRP 3\% and control (3\%fat).Also, there isn't significant differences in protein content of inulin 3\% and control (free fat). These findings might be related to the increase in the protein and ash content of $\mathrm{CRP}$, and these results were in harmony with Massoud et al., (2009) who reported that the roots of chicory were of 4.65 and $4.25 \%$ of crude protein and ash, respectively.

Table 1. Chemical composition of fresh Biofermented milk containing different levels of chicory roots powder or inulin.

\begin{tabular}{lccc}
\hline Samples & Total solid (\%) & Protein (\%) & Ash (\%) \\
\hline $\begin{array}{l}\text { Control } \\
\text { (3\%fat) }\end{array}$ & $13.41^{\mathrm{D}}$ & $3.19^{\mathrm{E}}$ & $0.64^{\mathrm{E}}$ \\
Control & $10.69^{\mathrm{E}}$ & $3.32^{\mathrm{D}}$ & $0.74^{\mathrm{C}}$ \\
(free fat) & $13.50^{\mathrm{D}}$ & $3.72^{\mathrm{B}}$ & $0.80^{\mathrm{B}}$ \\
CRP 3\% & $16.21^{\mathrm{B}}$ & $4.14^{\mathrm{A}}$ & $0.88^{\mathrm{A}}$ \\
CRP 6\% & $14.22^{\mathrm{C}}$ & $3.33^{\mathrm{D}}$ & $0.78^{\mathrm{B}}$ \\
Inulin 3\% & $19.36^{\mathrm{A}}$ & $3.43^{\mathrm{C}}$ & $0.77^{\mathrm{D}}$ \\
\hline Inulin 6\% &
\end{tabular}

CRP: Fermented milk with $3 \%$ or $6 \%$ chicory roots powder. Data are means $\pm \mathrm{SE}$ for 3 replicates. Means with different superscript capital letters are significantly different at $p<0.05$.

Titratable acidity (TA) and $\mathrm{pH}$ : Titratable acidity (TA) and $\mathrm{pH}$ - value of bio fermented milk during the cold storage are summarized in Table 2. The addition of $\mathrm{CRP}$ and inulin increased $\mathrm{pH}$ - values of fresh biofermented milk, compared with fat free control, even though inulin (3\% and 6\%) resulted in the highest $\mathrm{pH}$ values. Data in at the same Table show that there were insignificant differences among CRP treatments and two types of control either with or without fat content. The $\mathrm{pH}$ values decreased with storage in all of the resultant treatments. The opposite trend of results was observed with respect to titratable acidity. Differences in $\mathrm{pH}$ values and TA were significant between treatment, but with less significance between storage intervals for each individual treatment. However, titratable acidity of samples containing CRP (3\% and 6\%), and those containing inulin $(3 \%$ and $6 \%)$ reached $>0.8$ after about 8 days. While the fat free control reached $0.9 \%$ after about 4days. Addition of CRP (3\%) and inulin (3\%) resulted in the lowest acidity, while the addition CRP of $(6 \%)$ and inulin $(6 \%)$ resulted in the highest acidity for fresh products. Titratable acidity increased during storage period in all treatments, which might be due to the starter culture activity. These results related are due to the activity of bacterial starter and the presence of inulin and CRP, which enhanced the activity of bacteria 
started. On the other hand, the addition of fibers did not affect the development of acidity during the storage of yoghurt as apparent from the close acidity of the different treatments (El-Nagar and Brennan, 2001).

Table 2. Changes in pH and Titratable acidity (TA) of bio-fermented milk containing different levels of chicory roots powder or inulin.

\begin{tabular}{lcccc}
\hline \multirow{2}{*}{ Product } & \multicolumn{5}{c}{ Storage period (days) } \\
\cline { 2 - 5 } & Fresh* & $\mathbf{4}$ & $\mathbf{8}$ & $\mathbf{1 2}$ \\
\hline \multirow{3}{*}{$\mathrm{pH}$ fat control } & $4.14^{\mathrm{Aa}}$ & $4.08^{\mathrm{Aa}}$ & $4.04^{\mathrm{Aa}}$ & $4.02^{\mathrm{Aba}}$ \\
Fat free control & $4.09^{\mathrm{Ab}}$ & $4.12^{\mathrm{Ac}}$ & $4.09^{\mathrm{ABb}}$ & $4.05^{\mathrm{ABCa}}$ \\
CRP 3\% & $4.14^{\mathrm{Aa}}$ & $4.06^{\mathrm{Aa}}$ & $4.08^{\mathrm{ABa}}$ & $4.06^{\mathrm{BCa}}$ \\
CRP 6\% & $4.16^{\mathrm{Aa}}$ & $4.04^{\mathrm{Aa}}$ & $4.13^{\mathrm{Ba}}$ & $4.07^{\mathrm{Ca}}$ \\
Inulin 3\% & $4.50^{\mathrm{Bc}}$ & $4.42^{\mathrm{Bbc}}$ & $4.30^{\mathrm{Cb}}$ & $4.12^{\mathrm{Da}}$ \\
Inulin 6\% & $4.72^{\mathrm{Cc}}$ & $4.52^{\mathrm{Bb}}$ & $4.10^{\mathrm{ABa}}$ & $4.01^{\mathrm{Aa}}$ \\
\hline \multicolumn{5}{c}{$\mathrm{Acidity}(\%)$} \\
3\% fat control & $0.71^{\mathrm{ABa}}$ & $0.81^{\mathrm{ABab}}$ & $0.96^{\mathrm{BCb}}$ & $1.00^{\mathrm{BCb}}$ \\
Fat free control & $0.63^{\mathrm{Aa}}$ & $0.75^{\mathrm{Aab}}$ & $0.83^{\mathrm{Abc}}$ & $0.91^{\mathrm{Ac}}$ \\
CRP 3\% & $0.77^{\mathrm{Aba}}$ & $0.94^{\mathrm{Bb}}$ & $1.00^{\mathrm{Bcb}}$ & $0.96^{\mathrm{ABCab}}$ \\
CRP 6\% & $0.91^{\mathrm{a}}$ & $0.94^{\mathrm{Bab}}$ & $1.08^{\mathrm{Cb}}$ & $1.02^{\mathrm{BCb}}$ \\
Inulin 3\% & $0.82^{\mathrm{ABa}}$ & $0.89^{\mathrm{ABb}}$ & $0.93^{\mathrm{Bb}}$ & $0.94^{\mathrm{ABb}}$ \\
Inulin 6\% & $0.91^{\mathrm{Ba}}$ & $0.88^{\mathrm{ABb}}$ & $1.00^{\mathrm{BCb}}$ & $1.03^{\mathrm{Cb}}$ \\
\hline
\end{tabular}

*After overnight cooling. CRP: Fermented milk with 3\% or $6 \%$ chicory roots powder

- Data are means $\pm \mathrm{SE}$ for 3 replicates. Means with different superscript capital letters (between groups at the same storage period "column") and small letters (within group at different storage period"row") are significantly different at $\mathbf{p}<0.05$.

Total volatile fatty acids (TVFA) and acetaldehyde content: The changes in TVFA during storage period are shown in Table (3). It could be observed pronounced gradual increase in the total volatile fatty acids (TVFA) in all treatments of fermented milks during 12days of cold storage. Addition of $\operatorname{CRP}(6 \%)$ and inulin $(6 \%)$ in the preparation of synbiotic-fermented milk increase of the TVFA in the fresh products. The TVFA gradually increased in synbiotic- yoghurt of different treatments with extending the storage period. The rate of increase in TVFA was much higher in treatments with $6 \%$ of CRP or inulin, compared to other treatments. There was a gradual increase in the TVFA, which could be attributed to the of bifidobacteria, which is unique in the production of 1.5 moles of acetic acid, as well as $1 \mathrm{~mol}$ of lactic acid as the end products of the fermentation process of $1 \mathrm{~mol}$ of glucose (Tamime, et al., 1995). Data illustrated in Table (3) also revealed that the addition of chicory roots powder at different levels (3 and $6 \%$ ) or inulin at the levels of (3 and $6 \%$ ) to synbiotic fermented milk significantly increased the acetaldehyde content during the first days of storage period. After 4 days of cold storage all samples showed a gradual reduction of the acetaldehyde content till the end of the storage period, which confirms the stimulatory effect of inulin or polysaccharides and minerals in chicory roots powder and strongly encouraged the production of flavor compounds.

The addition of inulin (6\%) and 3\% to fatty control had more acetaldehyde content than treatments with turn were higher than fat free control. Acetaldehyde content slightly increased during storage for about 4 days, and then decreased thereafter. However, this might be due to the ability of numerous lactic acid bacteria to reduce acetaldehyde to ethanol (Amer, et al.,1991 and Salama, 1993).

Table 3 . Changes in total volatile fatty acids (TVFA) and acetaldehyde content of bio-fermented milk containing different levels of chicory roots powder or inulin.

\begin{tabular}{lcccc}
\hline \multirow{2}{*}{ Product } & \multicolumn{5}{c}{ Storage period (days) } \\
\cline { 2 - 5 } & Fresh & $\mathbf{4}$ & $\mathbf{8}$ & $\mathbf{1 2}$ \\
\hline \multicolumn{5}{c}{ Total volatile fatty acids $(\mathrm{ml} 0.1 \mathrm{~N} \mathrm{NaOH} / 100 \mathrm{~g})$} \\
3\% fat control & $6.55^{\mathrm{Aa}}$ & $8.05^{\mathrm{Ab}}$ & $10.31^{\mathrm{Ac}}$ & $13.37^{\mathrm{Ad}}$ \\
Free fat control & $7.61^{\mathrm{Ba}}$ & $9.54^{\mathrm{Bb}}$ & $12.23^{\mathrm{ABc}}$ & $14.19^{\mathrm{ABd}}$ \\
CRP 3\% & $7.89^{\mathrm{BCs}}$ & $10.05^{\mathrm{Bb}}$ & $13.46^{\mathrm{Cc}}$ & $15.00^{\mathrm{Bd}}$ \\
CRP 6\% & $8.44^{\mathrm{Ca}}$ & $9.61^{\mathrm{Ba}}$ & $13.31^{\mathrm{Cb}}$ & $15.02^{\mathrm{Bc}}$ \\
Inulin 3\% & $8.01^{\mathrm{BCa}}$ & $10.04^{\mathrm{Bb}}$ & $11.90^{\mathrm{Bc}}$ & $14.90^{\mathrm{Bd}}$ \\
Inulin 6\% & $8.54^{\mathrm{Ca}}$ & $10.05^{\mathrm{Bb}}$ & $12.31^{\mathrm{ABc}}$ & $14.20^{\mathrm{ABd}}$ \\
\hline \multicolumn{5}{c}{ Acetaldehyde $(\mu \mathrm{mol} / 100 \mathrm{~g})$} \\
3\% fat control & $63.95^{\mathrm{Ab}}$ & $85.40^{\mathrm{Bb}}$ & $48.72^{\mathrm{Aa}}$ & $46.15^{\mathrm{Aa}}$ \\
Free fat control & $61.65^{\mathrm{Ab}}$ & $68.72^{\mathrm{Ab}}$ & $54.70^{\mathrm{ABa}}$ & $54.33^{\mathrm{Ba}}$ \\
CRP 3\% & $64.33^{\mathrm{Aab}}$ & $62.00^{\mathrm{b}}$ & $50.92^{\mathrm{Aa}}$ & $55.71^{\mathrm{BCab}}$ \\
CRP 6\% & $72.25^{\mathrm{Bc}}$ & $66.01^{\mathrm{Ab}}$ & $59.62^{\mathrm{BCb}}$ & $48.80^{\mathrm{Aa}}$ \\
Inulin 3\% & $63.38^{\mathrm{Cab}}$ & $69.23^{\mathrm{Ab}}$ & $64.24^{\mathrm{Cab}}$ & $58.00^{\mathrm{BCa}}$ \\
Inulin 6\% & $76.35^{\mathrm{Bb}}$ & $90.53^{\mathrm{Bc}}$ & $71.16^{\mathrm{Db}}$ & $59.01^{\mathrm{Ca}}$ \\
\hline
\end{tabular}

*After overnight cooling. CRP: Fermented milk with 3\% or $6 \%$ chicory roots powder.

Data are means \pm SE for 3 replicates. Means with different superscript capital letters (between groups at the same storage period "column") and small letters (within group at different storage period "row") are significantly different at $\mathbf{p}<\mathbf{0 . 0 5}$.

Lactic acid bacteria count: The changes in the viable count of Str. thermophilus, Lb. delbruekii spp. bulgricus and $B$. bifidum used in making synbiotic-yoghurt with $\mathrm{CRP}$ and inulin (3 and 6\%) during refrigerated storage are presented in Table (4). It could be observed that the addition of chicory roots powder (CRP) and inulin to fermented milk significantly increased the viability of Lb. delbruekii spp. bulgricus and B. bifidum bacteria. However, Lb. delbruekii spp.bulgricus were of the lowest counts, compared with Str. thermophilus (Table.4). After 8days of storage, the counts of $L b$. delbruekii spp. bulgricus sharply decreased with significantly different $(p<0.05)$ from its counts at zero time.

The counts of Lb. delbruekii spp. bulgricus decreased by $2 \log$ in all treatments at the ending of its shelf life. The same trend was with , Str. thermophilus counts, which was higher by at least $2 \log$ order than those for $L b$. delbruekii spp. bulgricus in yoghurt containing B. bifidum bacteria (Vinderola, et al., 2000). On average, the survival rate of Str. thermophilus was better than that of both Lb. delbruekii spp.bulgricus and bifidobacteria. These observations were in line with those of -Dave and Shah (1997). As given in Table (4) it could be noted that the addition of chicory roots powder and inulin to fermented milk significantly increased the viability of $B$. bifidum bacteria. However, the addition of inulin ( 3 and $6 \%$ ) to the milk was more effective than the addition of CRP (3\%) throughout the storage period. All of the resultant yoghurt were of a steady decline in the numbers $B$. bifidum . The decrease was more rapid for control with fat $(\mathrm{CF})$ and control without fat (CNF). The viability of bacteria in biofermented milk during storage was higher in the presence 
of CRP and inulin powder as compared with control samples (Table4). However a significant decline $(P<0.05)$ well was observed after 8 days in chicory roots and inulin powder, the viable counts of $B$. bifidum recommended well above the recommended limit of cells per gram of fermented milk up to 8 days of storage period. These results were consistent with the previously mentioned reports on the ability of Frucooliogsaccharide (FOS) to stimulate the viability of bifidobacteria in some of milk drink types (Shin et al., 2000 ). Stimulation of bifidobacteria in the human colon by FOS has also been demonstrated in human feed trails (Gibson et al., 1995; Roberfroid et al., 1998). The degradation of FOS by Fructofuronasidases of bifidobacteria can increase growth and short-chain FOS are fermented more quickly by bifidobacteria (Perrin et al., 2002).

Table 4. Effect of addition of chicory roots powder or inulin on lactic acid bacteria count in bio-fermented milk during storage period (days).

\begin{tabular}{lcccc}
\hline \multirow{2}{*}{ Product } & \multicolumn{4}{c}{ Storage period (days) } \\
\cline { 2 - 5 } Fresh* & $\mathbf{4}$ & $\mathbf{8}$ & $\mathbf{1 2}$ \\
\hline \multicolumn{5}{c}{ Str. thermophilus $(\log$ CFU/gm) } \\
3\% fat control & $10.52^{\mathrm{Cb}}$ & $10.37^{\mathrm{Db}}$ & $10.37^{\mathrm{Db}}$ & $9.13^{\mathrm{A}}$ \\
Fat free control & $10.30^{\mathrm{BCc}}$ & $10.18^{\mathrm{CDbc}}$ & $9.36^{\mathrm{Cb}}$ & $6.50^{\mathrm{A}}$ \\
CRP 3\% & $10.02^{\mathrm{Ad}}$ & $8.73^{\mathrm{Bc}}$ & $7.41^{\mathrm{Ab}}$ & $7.74^{\mathrm{A}}$ \\
CRP 6\% & $10.42^{\mathrm{BCd}}$ & $9.49^{\mathrm{BCDc}}$ & $7.98^{\mathrm{Bb}}$ & $6.20^{\mathrm{A}}$ \\
Inulin 3\% & $10.16^{\mathrm{ABb}}$ & $10.01^{\mathrm{Db}}$ & $7.28^{\mathrm{Aa}}$ & $6.51^{\mathrm{A}}$ \\
Inulin 6\% & $10.14^{\mathrm{ABc}}$ & $9.23^{\mathrm{BCb}}$ & $7.20^{\mathrm{Aa}}$ & $7.00^{\mathrm{A}}$ \\
\hline \multicolumn{5}{c}{ L.delbruckii ssp. bulgaricus $(\log \mathrm{cfu} / \mathrm{gm})$} \\
3\% fat control & $7.50^{\mathrm{Bc}}$ & 6.24 & $5.10^{\mathrm{Aa}}$ & $4.80^{\mathrm{Aa}}$ \\
Free fat control & $5.92^{\mathrm{Ac}}$ & $6.71^{\mathrm{Bc}}$ & $6.00^{\mathrm{Bb}}$ & $4.92^{\mathrm{ABa}}$ \\
CRP 3\% & $7.82^{\mathrm{Cc}}$ & $6.16^{\mathrm{Ab}}$ & $6.00^{\mathrm{Bb}}$ & $4.13^{\mathrm{ABa}}$ \\
CRP 6\% & $8.00^{\mathrm{Cd}}$ & $6.80^{\mathrm{Bc}}$ & $6.10^{\mathrm{Bb}}$ & $5.29^{\mathrm{ABa}}$ \\
Inulin 3\% & $7.32^{\mathrm{Bc}}$ & $7.06^{\mathrm{Cc}}$ & $6.54^{\mathrm{Cb}}$ & $5.37^{\mathrm{Ba}}$ \\
Inulin 6\% & $8.22^{\mathrm{Dd}}$ & $7.71^{\mathrm{Dc}}$ & $7.10^{\mathrm{Db}}$ & $5.86^{\mathrm{Ca}}$ \\
\hline \multirow{5}{*}{ B. bifidum $(\log \mathrm{cfu} / \mathrm{gm})$} & \\
3\% fat control & $7.22^{\mathrm{Ac}}$ & $5.85^{\mathrm{Ab}}$ & $5.64^{\mathrm{Bb}}$ & $4.85^{\mathrm{Aba}}$ \\
Free fat control & $7.15^{\mathrm{Ac}}$ & $6.21^{\mathrm{Bb}}$ & $4.80^{\mathrm{Aa}}$ & $4.62^{\mathrm{Aa}} \pm$ \\
CRP 3\% & $8.20^{\mathrm{Bd}}$ & $6.75^{\mathrm{Cc}}$ & $6.00^{\mathrm{Bb}}$ & $5.12^{\mathrm{BCa}}$ \\
CRP 6\% & $8.00^{\mathrm{Bd}}$ & $6.88^{\mathrm{Dc}}$ & $6.24^{\mathrm{BCb}}$ & $5.31^{\mathrm{Ca}}$ \\
Inulin 3\% & $8.16^{\mathrm{Bc}}$ & $7.00^{\mathrm{Eb}}$ & $6.70^{\mathrm{Ca}}$ & $6.42^{\mathrm{Da}}$ \\
Inulin 6\% & $8.61^{\mathrm{Cc}}$ & $7.56^{\mathrm{Fb}}$ & $7.53^{\mathrm{Db}}$ & $6.69^{\mathrm{Da}}$ \\
\hline "Aft ove
\end{tabular}

*After overnight cooling. CRP: Fermented milk with 3\% or $6 \%$ chicory roots powder.

Data are means $\pm \mathrm{SE}$ for 3 replicates. Means with different superscript capital letters (between groups at the same storage period "column") and small letters (within group at different storage period"row") are significantly different at $\mathbf{p}<0.05$.

\section{Rheological properties:}

The effect of fortification with chicory roots powder (CRP) or inulin powder at different levels (3 and $6 \%$ ) on curd tension and curd syneresis of fermented milk made of free fat milk are presented in Table (5). The given data indicated that the curd tension of treatments with $\mathrm{CRP}(6 \%)$ was higher than the control without fat treatment. On the other hand, control with fat treatment was higher than control without fat. Adapa and Schmictt (1998) reported that fat content greatly affects rheological and sensory properties. Fortification of yoghurt with chicory roots and inulin powder resulted in a significant $(p<0.05)$ increase in curd tension (Table
5). This increase might be due to the high content of inulin in chicory roots powder, which being highly soluble appears to enhance gel matrices. Blomsma (1997) found that the fat- substituting property of inulin is based on the products' ability to stabilize water into a creamy structure. Marshall and Rawoson (1999) proposed that the type of exopolysaccharide (EPS) and consequently the interaction of the polymer with the milk proteins during fermentation had an apparent effect on the rheological properties. Schaller-pvonly and Smith (1999) indicated that half of the amount of inulin may have the same desired effect as adding 100\%inulin. The syneresis of yoghurt was affect by the addition chicory roots and inulin powder used as shown in Table (5). Increased separation of whey from the resultant yoghurt was observed in the control without fat, which may be to low total solids. In all treatments (Table 5) increased levels of chicory roots and inulin powder increased curd synersis at both 30 and 120 minutes of holding time and their curd synersis values were lower than those of the control samples. Similar results were reported by Kalab et al, 1983 and Cerning et al., (1990) and El-Nagar and Brennen,( 2001).

Table 5. Rheological properties of fresh biofermented milk manufactured using fat free milk containing different levels of chicory roots powder or inulin.

\begin{tabular}{lccccc}
\hline & Curd & \multicolumn{3}{c}{ Curd } & Syneresis $(\mathrm{ml} / 100 \mathrm{gm})$ \\
\cline { 3 - 6 } Product* & Tension & 30 & 60 & 90 & 120
\end{tabular}

\begin{tabular}{llllll}
\hline 3\%fat control $38.80^{\mathrm{B}}$ & $14.90^{\mathrm{C}}$ & $16.90^{\mathrm{E}}$ & $19.90^{\mathrm{D}}$ & $21.90^{\mathrm{D}}$
\end{tabular}

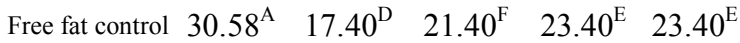

$\begin{array}{llllll}\text { CRP 3\% } & 54.16^{\mathrm{E}} & 9.90^{\mathrm{B}} & 14.40^{\mathrm{D}} & 19.40^{\mathrm{D}} & 19.40^{\mathrm{C}}\end{array}$

$\begin{array}{llllll}\text { CRP 6\% } & 57.18^{\mathrm{F}} & 9.90^{\mathrm{B}} & 11.40^{\mathrm{C}} & 13.90^{\mathrm{C}} & 14.40^{\mathrm{B}}\end{array}$

$\begin{array}{llllll}\text { Inulin } 3 \% & 47.87^{\mathrm{C}} & 9.40^{\mathrm{B}} & 9.90^{\mathrm{B}} & 10.90^{\mathrm{B}} & 10.40^{\mathrm{A}}\end{array}$

$\begin{array}{llllll}\text { Inulin } 6 \% & 51.41^{\mathrm{C}} & 7.40^{\mathrm{A}} & 8.40^{\mathrm{A}} & 8.90^{\mathrm{A}} & 9.90^{\mathrm{A}}\end{array}$

*After overnight cooling. CRP: Fermented milk with $3 \%$ or $6 \%$ chicory roots powder.

Data are means \pm SE for 3 replicates. Means with different superscript capital letters (between groups at the same storage period "column") and small letters (within group at different storage period "row") are significantly different at $\mathbf{p}<0.05$.

These results might be due to the addition of CRP or inulin which lead to mechanism for shear-induced disruption of the network prevented by expolysaccharides associated with the casein matrix. The present results are also came in agreement with these reported by (Hess et al., 1997) and Terry et at., (1999).

Organoleptic properties :

Organoleptic properties of resultant fresh biofermented milk with different levels of chicory roots powder and inulin (3 and 6\%) are shown in Table (6). The 3\% fat control scored higher for flavour and body $\&$ texture than those with free fat control. Results emphasized the importance of fat as a flavour modifier (Ohmes, et al.,1998). The bio-fermented milk with inulin $6 \%$ and CRP $6 \%$ followed the control with fat in the total scores.

As given in Table (6), it should be noted that no significant sensory differences were found between the control with fat and fermented milk with $6 \%$ of CRP or inulin. The fat -substituting property of chicory roots 
and inulin powder is based on the products ability to stabilize water into a creamy structure, which has an excellent fat like mouth feel and is almost taste free (Blomsma, 1997and Adapa and Schmictt, 1998). However, El-Nagar and Brennen, (2001) indicated that fat -free yoghurt containing $2 \%$ inulin superior to other treatments it has an acceptable consistency and smooth texture. The present results agree with those observed by Blomsma, 1997 and Tungland (2000).

Table 6. Organoleptic properties of fresh biofermented milk manufactured using fat free milk containing different levels of chicory roots powder or inulin.

\begin{tabular}{lcccc}
\hline $\begin{array}{l}\text { Fermented } \\
\text { millks }\end{array}$ & $\begin{array}{c}\text { Flavor } \\
(\mathbf{6 0 )}\end{array}$ & $\begin{array}{c}\text { body\& } \\
\text { texture } \\
\mathbf{( 3 0 )}\end{array}$ & $\begin{array}{c}\text { Appearance } \\
(\mathbf{1 0 )}\end{array}$ & $\begin{array}{c}\text { Total } \\
\mathbf{( 1 0 0 )}\end{array}$ \\
\hline 3\% fat control & $53.08^{\mathrm{B}}$ & $24.74^{\mathrm{B}}$ & $8.25^{\mathrm{B}}$ & $88.27^{\mathrm{B}}$ \\
Free fat control & $47.40^{\mathrm{A}}$ & $22.23^{\mathrm{A}}$ & $7.34^{\mathrm{A}}$ & $76.97^{\mathrm{B}}$ \\
CRP 3\% & $51.00^{\mathrm{B}}$ & $23.89^{\mathrm{AB}}$ & $7.57^{\mathrm{A}}$ & $82.46^{\mathrm{B}}$ \\
CRP 6\% & $51.69^{\mathrm{B}}$ & $25.25^{\mathrm{B}}$ & $8.35^{\mathrm{B}}$ & $85.29^{\mathrm{B}}$ \\
Inulin 3\% & $51.20^{\mathrm{B}}$ & $23.60^{\mathrm{AB}}$ & $7.40^{\mathrm{A}}$ & $82.20^{\mathrm{B}}$ \\
Inulin 6\% & $50.40^{\mathrm{B}}$ & $25.60^{\mathrm{B}}$ & $8.16^{\mathrm{B}}$ & $84.16^{\mathrm{B}}$ \\
\hline
\end{tabular}

*After overnight cooling. CRP: Fermented milk with 3\% or $6 \%$ chicory roots powder.

Data are means \pm SE for 3 replicates. Means with different superscript capital letters (between groups at the same storage period "column") and small letters (within group at different storage period "row") are significantly different at $\mathbf{p}<0.05$.

\section{CONCLUSION}

The above mentioned results indicated that addition of chicory roots powder or inulin (especially addition of $6 \%$ ) had a beneficial effect and improved the quality, the safety and the acceptability of the manufactured free fat control. So, it can be strongly recommended to use such materials (chicory roots powder and inulin) for preparing different types of bio- fermented milk for human consumption, especially for healthy effects.

\section{REFERENCES}

Adapa, S. and Schmite, K. A. (1998): Physical properties of low- fat sour cream containing exopolysaccharideproducing lactic acid. J. Food Sci., 63: 901.

Amer, S.N.; Moussa, A. E; Anis, S.M. K and Salama, F. M. (1991): Comparative study between Biograde as a new product and Zabady. Egyptian J. Appl. Sci. 6:667.

Blomsma, C. A. (1997): A review of commercial applications. International food ingredient. March/April pp22-23.

Causey, J.; Feirtag, J.; Gallagher, D.; Tingland, B. and Slavin ,J. (2000): Effect of dietary inulin on serum lipids, blood glucose and the gastrointestinal environment in hyper cholesterolemic men. Nutr Res 20, 191-201

Cerning, J.; Bouillanne, C.; Demasead, M.J. and Landon, M. (1990): Exocellular polysaccharides produced by lactic acid bacteria. FEMS Microbiology Reviews, 87:113-130.

chandrasekhara, M. R.; Bhagawan, R. K.; Swaminathan, M. and Subrahomanyan, V. (1957): The use of mammalian milk and processed milk foods in the foods in the feeding of infants. Indan J. Child. Health, 6:0701
Dave, R. I., and N. P. Shah. (1997): Viability of yoghurt and probiotic bacteria in yoghurts made from commercial starter cultures. Int. Dairy J. 7:31.

Dello-Staffoloa, M.B.; Bertolaa, b, M.; Martinoa, b. and Bevilacquaa, A.Y. (2004): Influence of dietary fiber addition on sensory and rheological properties of yogurt . International Dairy Journal 14: 263.

El-Farra, S.A. (1989): Studies on Production of Diabetic Drinks. Ph.D. Thesis, Food Technol. Dept., Fac. Agric., Cairo Univ., Cairo, Egypt.

El-Nagar, C.F. and Brennan, C. S .(2001): The influence of fiber addition on the texture and quality of stirred yoghurt. Proc. 8Th Egyptian Conf. Dairy Sci.\&Techn.505-523.

Gibson, G. R.; Beatly, E.R.; Wang, X. and Cummings, J. H. (1995): Selective stimulation of bifidobacteria in the human colon by oligofructose and inulin. Gastroenterology, 108: 975.

Hassan, F. A. M.; Helmy, W. A. and Enab, A. E.(1999): Utilization of some local polysaccharide in manufacture of yoghurt. Egyptian J. Dairy Sci. $27: 281$

Hess,S.J.; Roberts, R. F. and Zeigler, G.R. (1997): Rheological properties of nonfat yoghurt stabilized using Lactobacillus delbrueckii subspp. bulgaricus. J. Dairy Sci., 80: 252.

Kalab, M., Allan-Wojtas, P and Phipps-Todd, B.E. (1983): Development of microstructure in setStyl nonfat yoghurt- A review. Food Microstructure 2:51-66.

Kosikowski, F. V. (1978): Cheese and Fermented Milk Food. 2nd Ed., Published by the author, Cornell Univ., Ithaca, New York, USA.

Lees, G.J and Jago, G. R. (1969): Methods for the estimation of acetaldehyde in cultured dairy products. Australian J. Dairy Techno., 24: 181.

Li, D. J. ;Kim, J. M.; Jin, Z. and Zhou, J. (2008): Prebiotic effectiveness of extracted from edible burdock. Anaerobe. 14:29-340.

Ling, E.R. (1963): A Text Book of Dairy Chemistry. Vol. 11, Practical. 3rd Ed. Chapman and Hall, London., UK.

Marshall, V. M. and Rawson, H. L. (1999): Effects of exopolysaccharide-producing strains of thermophilic lactic acid bacteria on the texture of stirred yoghurt. International Journal of Food Science and Technology, 34: 137.

Massoud M. I.; Wafaa, A. Amin and Elgindy, A. A (2009): Chemical and Technological Studies on Chicory (Cichorium Intybus L) and Its Applications in Some Functional Food. J. Adv. Agric. Res. (Fac. Ag. Saba Basha).

Metchnikoff E..The prolongation of life. New York, 1907,Arna Press

National Research Council (NRC).(1989): Diet and health implication for reducing chronic disease risk. Common diet and health, food and Nutr. Board, commission on life sciences Nat., Res., Council National Academy Press. Washington, D.C. U. S. A.

Niness, KR (1999): Inulin and oligofructose: what are they? Journal of Nutrition 129: S1402.

Ohmes, R.L. ; Marshall, R. T. and Heymann, H. (1998): Sensory and physical properties of ice creams containing milk fat or fat replacers. J. Dairy Sci., 81: 1222 . 
Park, K. J.;de Oliveriam R. A. and Brod, F. P. R. (2007): Drying operational paramaters influence on chicory roots drying and inulin extraction. Trends I Chem E, Part C. Food and Bioproducts Processing. 85:184-192.

Perrin, S., Fougnies, C., Grill, J.P., Jacobs, H. and Schneider, F. (2002): Fermentation of chicory fructo-oligosaccharides in mixtures of different degrees of polymerization by three strains of bifidobacteria. Canadian Journal of Microbiology, 48: 759.

Roberfroid, M.B., Van Loo, J.A E. and Gibson, G.R. (1998): The bifidogenic nature of chicory inulin and its hydrolysis products. J. of Nutrition, 128: 11.

Salama, F. M. (1993). Chemical and organoleptical properties of biogarde from lactose-hyrolysed milk. Egyptian J. Dairy Sci. 21:273.

Schaller-povolny, L. and Smith, D.(1999): Sensory attributes and storage life of reduced fat ice cream as related to inulin content. J. Food Sci. 64: 555.

Shin, H.S., Lee, J.H., Pestka, J.J. and Ustunol, Z. (2000): Growth and viability of commercial Bifidobacterium spp. in skim milk containing oligosaccharides and inulin. Journal of Food Science, 65: 884.

Spiegel, J., Rose, R., Karabell, P., Frankos, V. and Schmitt D. (1994). Safety and Benefits of fiuctooligosaccharides as food ingredients. Food Technol. 48(1):85.

Steel, R.G. and Torrie, J.H. (1980): Principles and procedures of statistics. Abiometrical approach. 2nd Ed. (pp. 120) McGraw-Hill Book Co., New York, USA.

Tamime, A. Y; Marshall, V. M. and Robinson, R. K. (1995): Microbiological and technology aspects of milks fermented by bifidobacteria. J. Dairy Res., 62: 151 .

Taper, H. S., Delzenne, N. \& Roberfroid, M. (1997): Growth inhibition of transplantable mouse tumors by non-digestible carbohydrates. Int. J. Can. 71: 1109-1112.
Taper, H. S., Delzenne, N., Tshilombo, A. \& Roberfroid, M. (1995): Protective effect of dietary fructo-oligosaccharide in young rats against exocrine pancreas atrophy induced by high fructose and parital copper deficiency. Food Chem. Toxicol. 33: 631-639.

Terry, H., Rupnow, J., Boeckner, L. and Schnepf, M. (1999): Influence of long - and short - chained inulin on the firmness and sclerosis of nonfat yogurt. IFT Annual Meeting Technical Program Abstracts. 658-23, 178.

Tharmaraji, N. and Shah, N.P. (2003): Selective enumeration of Lactobacillus bulgaricu, Streptococcus thermophilus, Bifidobacteria, Lactobacillus casei and Propionibacteria. J. Dairy Sci., 86: 2288.

Tungland, B. (2000): A call for dietary fiber status for inulin. Cereal foods World. 45: 413.

Vinderola, C.G., Bailo, N. and Renheimer, J.A. (2000): Survival of probiotic microflora in Argentinean yoghurts during refrigerated storage. Food Research International, 33: 97.

Wang, S.T.;Barringer, S.A. and Hansen, P.M.T. (1998): Effects of carboxy-methyl-cellulose and guargum on ice crystal propagation in a sucrose-lactose solution. Published by El-Sevier Science Ltd. Food Hydrocollloids 12: 211.

Yadav A., Pallavi Jaiswa, Mithilesh Jaiswa, Nitin Kumar ,Rohit Sharma, Shailendra Raghuwanshi, G.B.K.S. Prasad, Prakash S Bisen, (2015): Concise Review: Importance of Probiotics Yogurt for Human Health Improvement. IOSR Journal of Environmental Science, Toxicology and Food Technology (IOSR-JESTFT).Volume 9, Issue 7 Ver. II, PP 25-30

Zbikowska, A. and Z. Zbikowski, (1996): Functional properties of UF concentrate]. Przemysl Spozywczy, 50: 32-34, (In Polish).

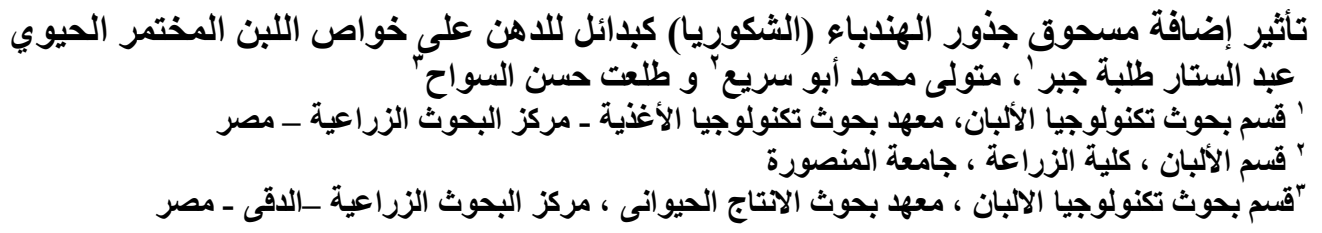

تهتم الدر اسة الحالية بالأغذية الوظيفية لمالها من أهمية غذائية و صحية ،حيث تم تدعيم اليو غورت المصنية الئنع من لبن خـالى من الدهن باستخدام

م.bifidum

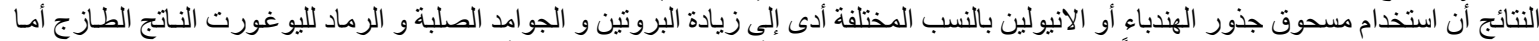

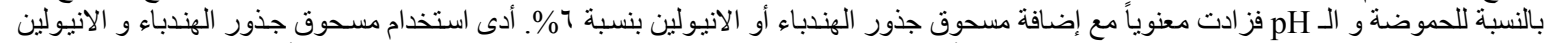

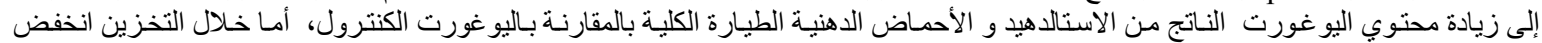

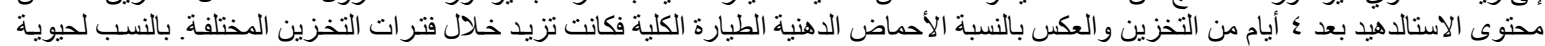

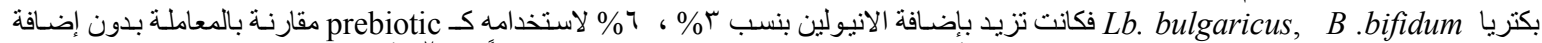

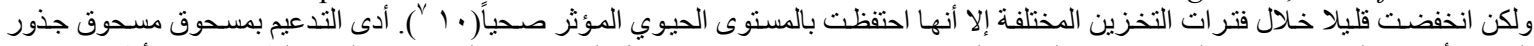

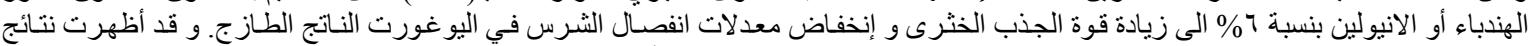

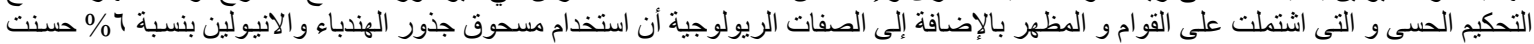

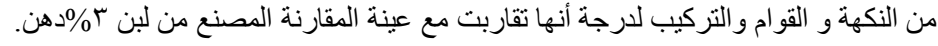

